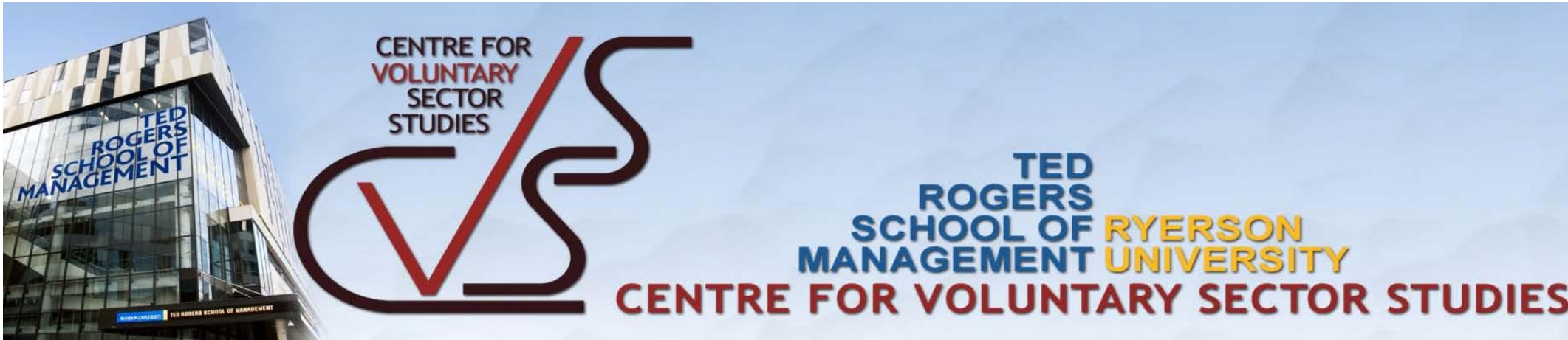

\title{
Entrepreneurial Ventures in Nonprofit Organizations: Determining Probability for Success
}

\author{
Susan Fitzrandolph \\ Centre for Voluntary Sector Studies, Ryerson University \\ Leslie Miller
}

Working Paper Series

Volume 1999 (2)

350 Victoria Street

Toronto, Ontario, M5B 2K3

Tel: (416) 979-5000 x 6739 / Fax: (416) 979-5124

cvss@ryerson.ca

http://www.ryerson.ca/cvss/working_papers/ 


\title{
ENTREPRENEURIAL VENTURES IN NONPROFIT ORGANIZATIONS: DETERMINING PROBABILITY FOR SUCCESS
}

\author{
Susan FitzRandolph and Lesley Miller \\ Centre for Voluntary Sector Studies \\ Faculty of Business, Ryerson Polytechnic University
}

\section{INTRODUCTION:}

In a recently published document entitled "Charities doing Commercial Ventures: Societal and Organizational Implications", (1998), Brenda Zimmerman and Ray Dart point out that even though charities have been undertaking commercial ventures for years, it would appear that we are poised for a dramatic increase in commercial activity. In response to government support radically decreasing, the phenomenon of nonprofit organizations taking on entrepreneurial ventures to generate additional resources is gaining momentum.

According to a 1995 study of member agencies undertaken by the United Way of Greater Toronto, $30 \%$ of respondents were involved in an entrepreneurial venture, while $12 \%$ were in the planning stages. More recently, a North American association of agencies serving children is launching its own "Venture Fund" designed to explore and create new business opportunities for member organizations. Edward Skloot, editor of The Nonprofit Entrepreneur (1988), describes nonprofit enterprise as existing along a spectrum of activity starting with traditional fee-for-service charges and extending into full-scale commercial activity. He categorizes nonprofit entrepreneurial activities according to the product or service being sold in the commercial arena. His categories include: program related products and services, hard and soft property and staff and client resources.

One common theme running through all the literature on this topic is that undertaking any type of commercial enterprise results in fundamental changes to the nonprofit organization. In their 1998 study, Zimmerman and Dart point out that commercial ventures, even when undertaken merely to replace lost grants, may fundamentally shift the nature of the organization. They go on to say that commercial sources of revenue require a different way of organizing and thinking for many charities which may affect anything from the overall culture to the process of decision making used by the charity It can also affect how the organization is structured, who works or volunteers for the charity and the mission capacity of the charity.

Considering these changes and the fact that the planning and development of a venture can often take at least twelve months, it is critical to offer some assistance to nonprofit organizations going into such a complex undertaking. The purpose of this research is to provide some insight into the organizational assessment that needs to be carried out prior to undertaking an entrepreneurial venture. For purposes of this research, entrepreneurial ventures are defined as activities which involve selling products or services for the purpose of generating revenue that is used to support the provision of the nonprofit services of the "mother" organization.

\section{BACKGROUND TO THE RESEARCH:}

In 1995, the ground was shifting for charities in Ontario. Charities that had always received the bulk of their funding from government now faced radical reductions of those funds. At the same time there was increasing competition for charitable contributions from corporations and 
individuals. In response to these new fiscal realities, nonprofit, charitable organizations were becoming interested in exploring new ways to generate resources.

In the spring of 1996, the researchers were asked by the Ontario Community Support Association (OCSA) to design a course to be delivered to their member organizations, which were facing radical funding cuts. The course would ultimately be named "Flourishing in Tough Times" and was designed to provide new ways of thinking and entrepreneurial tools to participants.

In the process of designing the course, the researchers explored the literature (theoretical and practitioner) and found almost nothing set in the Canadian context or even in analogous sociopolitical environments. There were prescriptive stories based on successful experiences in the United States. These stories have some similarities, but also vast differences including legal and tax implications. The nonprofit, charitable organizations that were to be participants in the course were set up to provide service and received their funding from government, and to a small extent, private sources. The need to create revenue was outside their framework of their experience. Whereas many of the stories that had considerable depth came out of a community development context where the charity was set up specifically with the intention of creating revenue.

The five-session course began in the fall of 1996 and was offered four times over a ten month period. Over 100 senior staff and board members from all over Ontario participated in the sessions. During the course, the participants raised many issues and questions. Not only did they have difficulty adapting to the concept of nonprofit enterprise, they also struggled with how to determine if the investment of time, money and energy would be worth their while. In fact, what many people were looking for was a recipe based on specific examples. "Show us organizations that we can identify with, what are their stories, what can we learn from their successes and failures?" were the types of requests heard. Underlying their questions was a real fear and the belief that "nobody has gone this way before." Despite an extensive search, the researchers were unable to find cases in a Canadian context, where the conflicts and failures of entrepreneurial ventures that were experiencing difiiculties were described or the internal/external organizational tensions addressed.

\section{LITERATURE:}

A review of the existing literature highlights the need for creativity and marketing. Brinkerhoff (1994) noted that the very language "making a profit" is problematic and that a new mindset is needed. Collins (1996) found that there was a fundamental difference in belief systems of nonprofits that needed to change; from"can't do good if doing well" to "can combine doing well with doing good."

Emerson, (1997) notes a number a traps for nonprofits embarking on an entrepreneurial venture. One is that nonprofits fail to understand that there is a the difference between responding to a social need and to a market demand. Another potential trap is failing to study the chosen location and what kinds of businesses have thrived and failed there. It is almost as though some nonprofits believe that because they do good, customers will naturally support their commercial enterprise. They also fail to realize how much it costs to start an entrepreneurial venture, in terms of money, time and organizational energy. Another major issue according to Emerson is that the goal of starting the business should be consistent with the mission. "While necessity may be the mother of invention, successful enterprises evolve $75 \%$ out of passion and $25 \%$ out of desperation". (p.20) He notes that "most nonprofits have a poor grasp of financial accounting, don't understand the markets they are entering, misread their consumers and don't anticipate staff/board opposition to creating a business." (p.20) 
There have recently been some attempts to deal at a meta level with the issues of internal/external tensions, still from a prescriptive position. Dees (1998) has created a Social Enterprise Spectrum on which he shows the range of available options to nonprofits as they seek to reduce their organization's dependence on government funding and to enhance their mission related performance. The Social Enterprise Spectrum "demonstrates the range of commercialization in terms of a nonprofit's relationships with its key stakeholders." (p. 60) He notes that many nonprofits with entrepreneurial ventures (social enterprises) are "actually multi-unit operations that run programs with different financial objectives and funding structures." (p.66) He states that "if nonprofits are to explore commercial options, it is essential both that they build business capabilities and that they manage organizational culture." (p.66) Nonprofits need to acquire the business skills and often end up hiring to provide the necessary expertise internally despite the skills brought by board members and partners from the business world. However, introducing people with different professional training and values will cause cultural conflicts within the organization. Also, the organization may have to pay more compensation to get the needed business skills then it does to internal staff members with comparable levels of education and experience, and thus compensation issues arise. In some cases, organizations have segregated the commercial activities from the philanthropic operations. There is still the danger of a "we-they" tension developing, feelings that those involved with the venture are not only paid more, but also receive more respect.

Much of what is presently known about the actual success or failure of entrepreneurial ventures comes out of the American experience and tends to be anecdotal. There are many "how-to" manuals to assist Canadian nonprofit organizations but little has been written documenting benchmarks and operating characteristics for success. Particularly, there is little information on the key internal organizational behaviours and structures and the key relationships with the external environment that can be said to lead to success. The literature to date presents an expert position, is based on American data, sets out questions to be asked and gives an approach on how to answer them. The case studies presented in this paper provide a vehicle for the search for information in a Canadian context. The research focuses on how business terms and behaviours are actually enacted in the organizations studied.

\section{RESEARCH QUESTION:}

This paper presents a qualitative investigation of the following research question:

Are there key indictors that can assist nonprofit organizations embarking on entrepreneurial ventures to determine their probability of success, prior to the investment of organizational capital?

\section{METHOD:}

The questions raised by the "Flourishing in Tough Times" course participants challenged the researchers to take an in-depth look at what was happening in several charities that were involved in entrepreneurial ventures. This exploratory research, using a qualitative case study method, investigated four Toronto area nonprofit, charitable organizations involved in entrepreneurial ventures for at least one year. These four organizations, representing different aspects of the nonprofit world - environment, credit counselling, hospice and in-home support, were set up to provide service and historically received the majority of their funding from government and private sources. Over the period of a year, case studies were developed on the four organizations using a combination of qualitative methodology: interviews, observation and review of historical data. The methodology used was noninterventive, empathic and preserved the multiple realities of what was happening. The iterative activities of the researchers included entry into the organization and trust 
building, review of background data, observation of organizational life, interviews of key informants (at least three individuals from each organization), and validation of the data obtained.

\section{GATHERING THE DATA:}

The research, which was accomplished in two phases, ultimately involved four organizations. The four cases were chosen in a serendipitous and opportunistic manner. In one organization, the manager had been a participant in the "Flourishing" course; another was recommended by a colleague; in the last two one of the researchers had previously provided strategic planning consultation to the organizations. Although the researchers had no preconceived categories when the research began, their study of the literature and experience with course participants framed Phase I of the research. Employing an emergent design, semi-structured interviews were conducted with key players in both the organizations and in the ventures. The researchers interviewed as a team to ensure a dual perspective. They began interviews from the position that the interface between the "mother" organization and the venture was critical, as were the dynamics and issues that surrounded the original decision to commit to the venture.

Four themes emerged from the chaotic field of Phase I data :

Theme 1 Evidence of business acumen in relation to the external environment of the organization,

Theme 2 Evidence of business acumen in relation to the internal environment of the organization,

Theme 3 Evidence of support for the venture from the external environment of the organization; and,

Theme 4 Evidence of support for the venture from the internal environment of the organization.

These four themes assisted in the development of a set of semi-structured interview questions used to gather data in the Phase II two cases. These interview questions can be found in Appendix I.

Throughout the interview process, the researchers consistently observed that the informants, who came from a variety of levels in the organizations, often had difficulty answering the questions directly and completely. Interviewees seemed to have two problems: one, use of business language did not come easily to many of them and two, separating issues related to the venture from those related to the policies and services of the "mother organization" was an almost impossible task.

\section{CASE STUDIES}

\section{CASE \#1 - Reduce, Reuse, Recycle (RRR)}

\section{Description of the Organization:}

Reduce, Reuse, Recycle (RRR) was founded in 1978 to assist the growing number of small volunteer and commercial recycling operations which were springing up across Ontario. This membership organization has always involved itself with a broad cross-section of interested parties. Although often seen as part of the establishment, RRR sees its role as bridging the diverse interests of environmental organizations, government and industry, business, media and educational institutions. With a revenue base of nearly $\$ 900,000$, it is the largest not-for-profit group of its kind in Canada or the United States. 
Its emphasis has been on formulating policies that will reduce waste and has a history of taking positions on such issues as junk mail, waste export and used motor oil. It offers public education opportunities, research services, waste minimization awards and sponsors Waste Reduction Week and the Recycling Fashion Awards. For RRR maintaining the delicate balance between advocacy and working with industry is a constant challenge.

The core values of the organization are evident when one enters their offices, which are housed in an older office building located close to the industrial area of town. Tables and wall coverings made from recycled materials, staff members arriving on bicycles, public transportation and by foot, impart a strong message that emphasizes minimizing environmental damage. There is no parking lot.

In 1995 the organization was faced with a substantial reduction in provincial government funding. This created a shake-up of the organization that resulted in 10 staff members ultimately being laid off by the end of that year. In an effort to do more with less and put some funding parameters in place, the board of directors agreed that all programs must have their own funding source and be self-sustaining. This policy caused the project managers to compete with each other for funding, often from the same sources. As an interviewee said, "When the watering hole begins to dry up, the animals begin to look at each other differently."

\section{The Venture}

In an effort to implement new funding possibilities, the idea for an auto recycling venture was brought to board in August 1995. The concept was originally rejected after initial analysis as it seemed risky. Firstly, it required significant up front investment to cover the cost of promotion and staff salary and secondly, there seemed to be a potential conflict with core values. A more detailed analysis was undertaken and the proposal was again brought to the board. The board, recognizing the pressing need for new sources of revenue, reviewed the business plan and decided that the benefits outweighed risks. They agreed to use reserve funds as start-up capital for the venture.

The auto recycling venture was undertaken in partnership with the Vehicle Recycling Organization (VRO) and was endorsed by the government Environment Ministry. Its goal was "to facilitate the pick-up and dismantling of automobiles". Revenue is generated when a car is removed, at no cost, from an individuals' property and is dismantled for sale of the parts. VRO assesses the value of the donated car and pays RRR that value. The owner receives a tax receipt for that amount $(\$ 75.00$ or greater) and VRO receives an administration fee from RRR.

Despite the fact that several other charitable organizations were undertaking similar ventures, the market for the venture was potentially very large. More than 400,000 cars were being removed from provincial roads annually and RRR believed that "the competition couldn't catch them."

The venture champion, who had considerable entrepreneurial experience, began work as the project manager in March of 1996. The venture was officially launched in July of that year. During the first five months of operation, the venture grossed more than $\$ 100,000$ toward RRR programs. By the end of the first year, the venture provided $25 \%$ of RRR's operating budget.

An aggressive public relations program was implemented including a brochure and press releases to the print media. More than 4,000 people phoned the RRR's toll free number in the first year of operation. The public response was so great that it initially overwhelmed the phone system of the organization. 
After an initial shake out, the venture settled down and was run by the project manager and one administrative support person (who was hired on an employment grant). A software program was adapted by the manager to efficiently record information and process tax receipts. The offices were located within the RRR offices and infrastructure support was provided by RRR.

In its second year, the venture began to take on a life of its own and operated somewhat independently. It appeared to receive little recognition from the "mother organization" ( for example, it was not included in an organizational brochure that highlighted RRR initiatives. In addition, other RRR programs saw it as a competitor for fundraising sources in the auto industry.

After the first year, the number of calls dropped off, as did the project revenues. It appeared that the successful publicity campaign, that had worked so well in the first year, was not necessarily reaching the right prospective customers. The executive director, with a background in advertising and sales, felt that an aggressive program of paid, strategically placed advertising was needed. Meanwhile, the project manager whose strength lay in obtaining free publicity, felt a large advertising expenditure was unnecessary. The pressure to increase revenues, combined with the differences in strategy and approach between the executive director and the project manager, created a major source of tension in the organization.

The organization continues to struggle with the difference in management involvement in one-off events (with which there was a great deal of experience) and in a continuing program (new experience for all). Setting realistic projections and understanding the cyclical nature of this particular offering will create challenges in the next phase of the venture. The hands-on management style used for one-off events does not easily translate over a long period of time without a process in place to deal with inevitable differences of opinion. This too will form a challenge for RRR in the future.

\section{Case \#2 - HOME SUPPORT SERVICES (HSS)}

\section{The Organization}

Located in a middle class neighbourhood of a large Canadian city, Human Support Services (HSS) is in a neighbourhood made up of other non-profit organizations, small businesses, and apartments. Its building is a striking, multi level modern edifice with the logo placed on the front in a way that not only identifies the organization, but also pleases the eye. There is a large, adjacent parking lot in the back for use by staff and visitors.

Upon entering, the visitor is greeted at a large reception desk where a phone operator easily switches between French and English when responding to clients calls. The office has an air of concentrated client service. This is captured in the slogan on the Annual Report - "Over 70 years of trusted caring service."

The mission of the HSS centres on developing and delivering social and health services on a "cost recovery" basis to individuals and families in its catchment area in order to prevent or delay institutional care or family breakdown. The stated values of HSS include:

- $\quad$ promoting access and encouraging ethno-cultural community participation in both the delivery and benefit of the service.

- $\quad$ providing professional health and social work support, and trained and professionally supervised in-home staff,

- $\quad$ supporting the social and health programs through "fee for service" programs,

- $\quad$ responding to changing needs and interests of the community, and

- using volunteers to enhance programs. 
HSS, which has an annual budget of $\$ 12,000,000$, operates with a staff of over 400 trained home support workers, supported by a health and social service staff of 38 and a management staff of 4 . In 1995, over $90 \%$ of its expenditures went to service provision. The assessment of client needs and the coordination of service provision forms the core business of this organization. Services include home support, homemaking services, home companion activities, respite care/giver relief, palliative care, foot care and manicure program (offered at no charge to those in need and on a feefor-service basis to the general public) and home cleaning services on a fee-for-service basis.

These services are available seven days a week, 24 hours a day from a multilingual, multicultural staff. The client groups include those from home care, Municipal Community Services and the general fee paying public (Both Visa and Master Card are accepted). HSS is a United Way member.

Founded in 1924, the organization has a long history of responding to the many changes in Canadian society. Its latest challenge is to respond to the call for "managed competition" in the health and social services sector.

\section{Start up of the venture:}

The Executive Director, who had previous experience with an entrepreneurial service in a nonprofit organization, saw both a need and an opportunity to introduce an entrepreneurial culture into HSS. Between 1994 and 1996, the provincial government moved from being a major source of revenue to a purchaser of service from the lowest cost bidder. The push for Long Term Care Reform coupled with a general public reaction against the rising costs of social and health services to an aging population, led to the realization that for HSS to survive, the organization must diversify its services and its sources of revenue. Competition had also become a major issue, both within the nonprofit sector and from private sector sources.

The Home Cleaners Program began in 1993 in response to this environment and to requests from potential customers who did not qualify for free homecleaning services. This fee-for-service program provides a full range of cleaning services to customers on an individualized schedule. Its motto is "We do windows... and everything else". The program development co-ordinator ensures reliable service to the general public through contracted, unionized and trained cleaning staff.

\section{Growth of the venture:}

Home Cleaning services grew rapidly in 1994 and 1995 and "earned the right to become part of HSS's core service mix". It provided 36,000 hours of homecleaning services to 500 clients, employed 40 people and generated a gross revenue of close to $\$ 600,000$. The program development co-ordinator not only championed the service but acted as salesperson, customer service representative, trainer, scheduler and co-ordinator.

The growth leveled off in 1995-6, forcing a re-examination of every aspect of the venture. It was thought that potential customers were confused and did not really see it as an alternative to other cleaning services. In the spring of 1997, marketing consultants, who were hired to help chart a course for HSS in order to "broaden the service mix both to address the diverse needs of our clients and to rebalance our revenue base", confirmed that nonusers had either never heard of HSS or had inaccurate information about it. The part of market research report which dealt with the home cleaning venture highlighted the need to communicate that home cleaning was a hassle-free solution offered by trusted professionals who care. In response to the report findings, the name of the program was changed to Better Home Cleaning, a new brochure was printed and distributed on a limited basis. 
At the same time, the program was more fully integrated into the HSS organizational structure. Hiring and training, instead of being done by the program development coordinator, was done by HSS's human resources department. The program development coordinator now shared a supervisor with other program coordinators and was physically located with them. This was a change from the start up when the venture operated as a completely separate enterprise.

\section{The Future}

Throughout the period that the Home Cleaning Service had been operating, the "mother organization" began to implement some changes that "respected the past, while signaling a shift for the future." A new name and logo, which communicated the "full service" aspect of the organization, was implemented. The board, which had been composed of traditional social service leaders, shifted to one of entrepreneurial thinkers and business people. A manager for the new marketing department was hired with responsibility for expanding existing initiatives and seeking strategic market alliances.

Recognizing that the home cleaning business is very competitive and that customer loyalty is exceptionally hard to achieve, HSS is considering partnering with real estate companies in order to reach a consistent, but ever-present market. The Home Cleaning venture is also distributing a new, improved brochure to specific target markets and is planning to undertake a focused advertising campaign.

\section{Case \#3 - REgIONAL HOSPICE PROGRAM}

\section{Background:}

Regional Hospice Program (RHP) is a nonprofit, charitable community organization that offers inhome, end of life care, at no cost to several communities that form part of a large metropolitan city in Ontario, Canada. It is dedicated to improving the quality of life for people in the advanced stages of illness, providing support to their families and caregivers, and promoting palliative care services.

The hospice was started in 1989 by an individual who, while involved in a pastoral rotation at a large regional cancer and trauma hospital, recognized a need for hospice services. Her background in nursing and hospice work in Great Britain provided the model for the Regional Hospice Program.

The hospice was originally located in a small office in the hospital and most of its board members were staff of the hospital. Although separately incorporated in 1990, there was always confusion over whether the hospice was a program of the hospital or a separate, distinct organization. As an example of this confusion, donations that were made to the hospice were often directed to the fundraising department of the hospital for receipt and then found their way into the hospital's general revenue.

The organization was essentially run by volunteers with a part-time coordinator. It received some provincial start up funding in 1990 , but had no stable source of on going income. In those early years, a large proportion of time was spent fundraising, while much less time was spent actually delivering the hospice program.

Since its inception, the hospice has seen tremendous growth. An aging population, coupled with increased credibility, has raised interest in hospice programs. In 1996, it provided over 5000 hours of service to 144 families. Hospice services include: 
- liaison and coordination with other home care services,

- bereavement counselling and group support sessions,

- $\quad$ spiritual support and liaison with client's faith community, and

- a lending library.

\section{The Venture:}

In 1994, the hospice opened a resale clothing shop called "Wear It Again". The shop was the brainchild of the founder of the hospice who modeled it on the "charity shops" in Great Britain. These charity shops, which have a long and respected history, support oncology and some hospice programs by raising large sums of money through the sale of donated clothing and accessories.

It was hoped that "Wear It Again" would create a more stable funding base for RHP. The store rented premises on a busy mid-town street where five other resale and consignment shops are also located. It was felt that this advantageous location, with a large amount of walk-by traffic, offered an opportunity for the hospice to raise its profile.

The main floor of the store is small and crowded with racks of clothes. Upstairs are fitting rooms, an old kitchen, now used as a pressing room, another showroom filled with markdowns and a small office which also doubled as a counselling room. In keeping with the British "charity model" and because the founder was well connected in the community, the store received a steady supply of expensive, gently used clothing. It also attracted a volunteer cadre of retirees from the surrounding middle class community, many of whom also shopped in the store.

During its first four and one half years of operation, the store employed two part time staff to cover a six day schedule. It also benefited from the commitment of six hundred volunteer hours per month contributed by forty volunteers. The store manager was a nurse with no retail experience. The assistant manager, also a nurse, acted as the volunteer coordinator for the shop and bereavement counsellor for the hospice. They were in the store separately for three days with one day when they overlapped. This schedule was advantageous as the two managers frequently disagreed on how the store should be run.

Since the store was set up in 1994, net revenues, after expenses, increased steadily reaching approximately $\$ 10,000$ per year. In 1997, there was a decrease in revenue and the board of RHP, which until then had paid little attention to the venture, began to take a closer look. The board, whose composition had shifted to include individuals with business and marketing experience, questioned whether an annual net revenue of $\$ 6,000$ justified the amount of staff and volunteer time spent operating the store. In addition, they recognized that issues of staff roles, maximizing store potential, image confusion and reporting methods needed to be addressed.

Other changes had taken place. The original founder, who had been the champion of the venture, had retumed to Great Britain. Without her community contacts, the quality and number of donor bags had dropped. The store manager retumed to her health care roots. A new, highly qualified Executive Director was hired for the hospice. With its move to community offices, the RHP became clearer on its identity and was actively seeking resources to increase the services it could provide. It was clear to the hospice board that the store was not achieving its full potential as a revenue producer.

The board and executive director realized that the original staffing roles reflected the informal nature of the hospice at its inception. The assistant store manager/hospice bereavement counsellor/volunteer coordinator was seeing clients at the store. She often had to ask the volunteers, who were sorting clothes, to move out of the only private space at the store. 
According to the present executive director, "the bereavement program was obviously totally sacrificed to operating the store". With the demand for counselling growing, it was decided to allow the bereavement counsellor to focus on counselling. At the same time, it was decided to hire an experienced retail manager to take responsibility for all aspects of the store's operations, including volunteer coordination, in order to maximize the store's potential.

The board and executive director also recognized the need to clarify the role of the store in relation to the hospice. Originally, the store was the only public face of the hospice. In fact, as well as displaying clothes, the store window also displayed books on dying and grieving. The public was confused as to what the store was and what the hospice was. Some saw the store as a program of the hospice, providing outreach, bereavement counselling and a lending library. In other cases, the store was seen as the fund raising and public relations arm of the hospice. For example, in its first year of operation, store staff were involved in eight separate fund raising events including barbecues at a local supermarket, bake and book sales and organizing a rummage sale. Still others saw the store as simply a place to get cheap clothes without connecting it to anything else. It was agreed that the new store manager would focus her attention on growing the store business and that a board/staff fundraising committee would be responsible for other types of fundraising.

Initially the store manager reported directly to the board, despite the fact that the board was unclear as to its role regarding the store. It was decided that the store manager should report to the executive director directly, in the same manner as other staff. There was also a decision to shift the type of reporting received. Whereas previous reporting had focused on the number of bags donated and the number of volunteer hours, reporting now entails revenue projections.

The changes are in place and are taking hold gradually. The bereavement books are out of the window and are now beside the cash register. More up-to-date clothing is displayed in the window, using a backdrop of antiques donated by neighbouring stores. The racks in the front of the store are arranged to promote easy browsing. Clothing bags are now distributed through a recently started community partners program. A move is a foot to attract younger customers and benefit from the growing popularity of "vintage clothing".

Today RHP continues to grapple with balancing the growth of the organization with the growth of the store. The role of the store in relation to the organization's main mission remains a sticking point, particularly when the number of volunteer hours invested in the store is three times the number of volunteer hours invested in core hospice services.

\section{Case \#4 - ENHANCED CREDIT COUNSELLING SERVICES (ECCS)}

* Please note that the original research interest in this organization was a specific undertaking that met the venture criteria. In fact what the researchers discovered was that rather than a specific activity, this whole organization had made a conscious choice to transform itself into an entrepreneurial venture. Although it differs from the previous three cases, its inclusion serves to highlight important indicators to other nonprofits undertaking entrepreneurial ventures.

\section{Background:}

The service of credit counselling, developed in the early 1960's in Canada and in the 1950's in the United States, provided people with the knowledge they needed to manage their finances in a world of exploding credit opportunities. The service has grown throughout North America where there now are more than 1300 credit counselling offices helping over 1,300,000 people annually. They provide more than 50,000 educational programs and disburse more than $\$ 2$ billion to creditors through debt management programs. 


\section{The Organization}

Enhanced Credit Counselling Services (ECCS) was set up to provide people from all income levels with no cost/low cost confidential financial counselling and to manage debt repayment for the creditors of their clients. It was incorporated as a nonprofit charity in 1966 and was funded $80 \%$ by the government and the United Way. The remainder of the financial resources came in the form of donations from the creditors of clients. Its mission is to help consumers with financial problems through education and counselling on personal budgeting, the wise use of credit, and planned debt management. The basic values which underscore the service provided by ECCS are:

- Provision of unbiased financial counselling to enable individuals to pay their debts, avoid bankruptcy and re-establish their credit standing; and,

- Educate individuals and families of every income level and national origin in the management of personal finances and credit.

Although its primary purpose is to serve clients, ECCS sees itself in a unique position as advocates of both individual creditors and of the larger financial system of which credit and lending plays a vital part. The relationship of this agency to the banks, retailers and other lenders is critical to its ability to provide the service to its clients. In 1997, ECCS served 15,765 clients, administered 2607 Debt Management Accounts $(\$ 32,000,000)$, had 12,905 participants in educational programs and serviced more than 150,000 telephone inquiries. The clients come from all walks of life with an average age of 41 and slightly more men than women.

ECCS is an accredited charter member of the provincial Credit Counselling organization and is affiliated with the National Foundation for Consumer Credit. In its 32 year history ECCS has disbursed over $\$ 80$ million for its clients and has helped more than 100,000 individuals and families through difficult economic times. It has grown from a small group of counsellors to 26 staff today who serve clients out of eight satellite offices, by phone and with the support of advanced technology.

Previously located in downtown Toronto, their main office had an air of quiet competence. Clients were greeted at the reception desk and shown to a small waiting room filled with posters and literature on gaining control of one's financial life. The organization has recently moved its headquarters to a more spacious, suburban location which has the capacity to facilitate telephone credit counselling.

\section{The Change}

In 1992 the government gave 3 months notice to all credit counselling agencies in Ontario that their provincial funding of was to be eliminated. Many of the credit counselling agencies sought partnerships with nonprofit Family Service Groups. These partnerships allowed the organizations to survive while not changing the ways in which they operated. However, ECCS decided that this was an opportunity to either radically change the way they were operating or to close the organization. While working to change the basic ethos of the organization, measures were put in place to enable closure of the organization, should it become inevitable. This included establishing a six month reserve and giving six month official termination notices to all staff. Six months prior to the government announcement, the ECCS Board had recognized that the agency could be providing more and better services and had invited a consultant from the private sector to examine its operations and make recommendations for improvement. The ensuing loss of funding gave the organization the impetus to move ahead on the recommendations. The organization made a conscious decision to "operate as a private sector organization while providing service like a nonprofit." 
A new Executive Director, who embodied the entrepreneurial spirit, was hired. In order to encourage the whole organization to become an entrepreneurial venture, the board and the senior staff made a conscious decision to change the organizational culture. The existing organizational culture was one of slow pace, service to those who requested it and a "welfare mentality" with a strong dependence on government funding. The clients were viewed as "poor folks who needed a helping hand". The first thing that was implemented was greatly increased performance expectations in terms of both numbers of clients seen and services provided.

New technology was introduced which resulted in greater ease and accuracy of record keeping on the one hand and much higher visibility of mistakes on the other. For a short time productivity dropped as people reacted to these new expectations. About $2 / 3$ of the staff were uncomfortable with the new productivity measures and emphasis on performance and chose to leave the organization. New staff were hired with the skills and attitudes that fit the new culture.

Prior to the change, the organization did not recruit clients. To some degree there was a feeling, prominent in social service organizations, that "those who require our services will find us" in addition to a fear that an increase in client numbers could not be met by the organization. All this changed with the new entrepreneurial outlook. The organization developed and implemented a marketing plan and although it did not have a formal business plan, all day to day decisions were driven by the entrepreneurial outlook.

The marketing plan included ways to reach groups who could use the services, but did not know of them. Advertisements were placed where potential clients were found. Seminars in secondary schools and universities, as well as speakers for events were provided. The organization developed a healthy two-way partnership with the press, providing in-depth stories which supported the topical issues of credit problems and at the same time advertised the services provided by the organization. The culture of the organization changed to meet the needs of the increase in clients and the change in type of client. Counselling services were now being provided to the middle class with credit problems as well as the "deserving poor". The removal of government funding encouraged the attitudes of the staff to change from a "welfare mentality" to "earning our way." Now the pace of work is brisk and the service, while friendly, is very efficient.

Entrepreneurial thinking is consciously diffused throughout the organization. Training and learning is continuous and well supported by time off and money. The champion for the entrepreneurial vision is the Executive Director who, with his strong charismatic style, has been able to bring all stakeholders with him.

All staff are well trained on the technology that links them to the creditors and other service users. They even sell the service of their technology to other credit counselling organizations. The organization is now totally funded through entrepreneurial activities including providing service to banks, other creditors, and bankruptcy trustees, who are potential competitors. ECCS is embarking on new ways of expanding their services through phone and internet counselling.

There is an atmosphere of always looking ahead, watching the trends and developing new services to meet emerging needs and, at the same time, support the organization.

One major sticking point has been the relationship of this agency with other agencies providing the same service in other locales. Many are still very much "social service" agencies who have found ways to remain funded by government. They live in fear of losing these resources, do not advertise because they fear an overwhelming increase in clients and are frightened of technology. Their general fear of change has led them to distrust and at times ostracize ECCS, which they see as "having sold out to the world of business". 


\section{DATA ANALYSIS}

\section{Development of the Indicators}

In order to make sense of the raw data, the researchers created a matrix using the 4 themes outlined earlier. An examination of the ordered data yielded 17 potential indicators for success that seemed important in all four organizations. The 17 indicators, illustrated in Exhibit I, are outlined in the form of questions following the Exhibit.

External Environment

\begin{tabular}{|l|l|}
\hline \multicolumn{1}{|c|}{ Quadrant \#1 } & \multicolumn{1}{c|}{ Quadrant \#2 } \\
\hline $\begin{array}{l}\text { Business plan } \\
\text { Market Awareness } \\
\text { Trends } \\
\text { Knowledge of the } \\
\text { Competition } \\
\text { Knowledge of the } \\
\text { Customer }\end{array}$ & $\begin{array}{l}\text { Decision-making } \\
\text { Management Expertise \& } \\
\text { Experience } \\
\text { Entrepreneurial Culture }\end{array}$ \\
& \\
\hline Quadrant \#3 & \\
\hline & \\
Current Funder, Donor \& & Quadrant \#4 \\
Client Support & "Champion" \\
Public Perception & Infrastructure Support \\
& Structural Integration \\
& Fit to Mission \& Values \\
& Organizational Culture \\
& Style of Management \\
& . \\
\hline
\end{tabular}

Exhibit 1: Indicator Matrix 


\section{Seventeen Potential Indicators for Success}

1. Does the organization have a business plan for the venture?

2. Do what degree is the organization aware of the venture's potential market?

3. What are the general trends around the service or product offered by the venture?

4. What is the level of knowledge of and attitudes toward the competition for the service or product provided by the venture?

5. What does the organization know about the potential customer for the venture?

6. How are decisions for the venture made?

7. What is the level of management expertise and experience in the organization and in the venture?

8. Does an entrepreneurial culture exist in the organization as well as in the venture*?

9. What are the attitudes of current funders, donors and clients towards the venture?

10. What is the public perception of the venture and its relationship to the organization?

11. To what degree does the board of the organization support the venture?

12. Who in the organization is the champion for the venture?

13. What kind of infrastructure is available to the venture?

14. What is the structural integration between the venture and the organization?

15. What is the fit of the venture to the values and mission of the organization?

16. How does the venture fit with the organizational culture?

17. What is the management style of the organization with regard to the venture?

* For the purposes of this research, organizational culture is defined as a pattern of shared beliefs, values and assumptions that govern the behaviour of the members of the organization.

J. Gregory Dees, in his research on social entrepreneurship, has developed a way of thinking about entrepreneurial cultures in nonprofit organizations as a shared way of looking at the environment that includes not being constrained by resources in hand but rather seeing opportunity and then leveraging and using resources. Entrepreneurial organizations value innovative ideas and exhibit a continuous process of adaptation and learning.

\section{APPLICATION OF THE INDICATOR MATRIX:}

The Indicator Matrix was used as a lens to re-examine the raw data that emerged from the of the cases. Exhibit 2, which follows, provides a summary of the application of the seventeen indicators to the data from the four cases. 
Exhibit 2

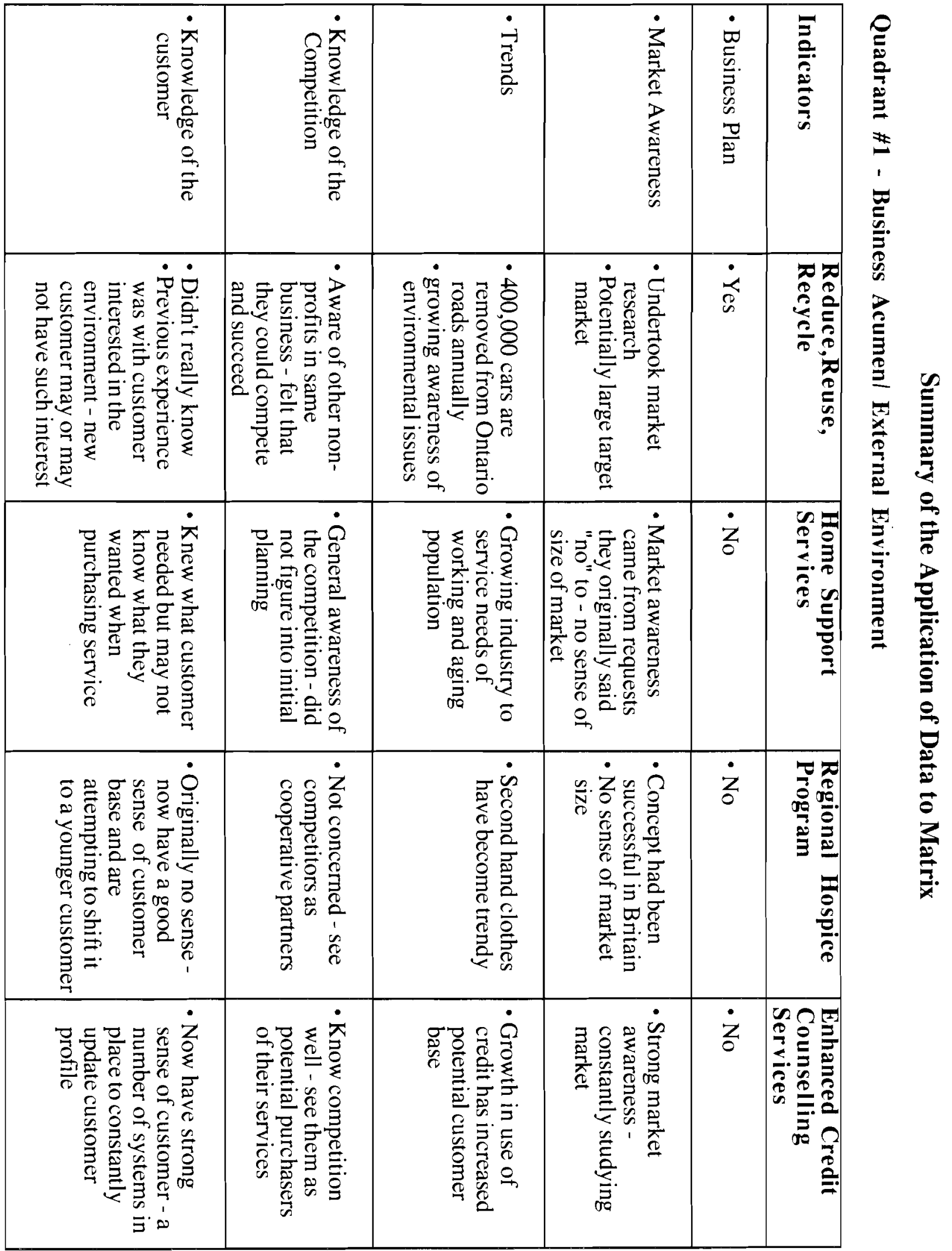




\begin{tabular}{|c|c|c|c|}
\hline 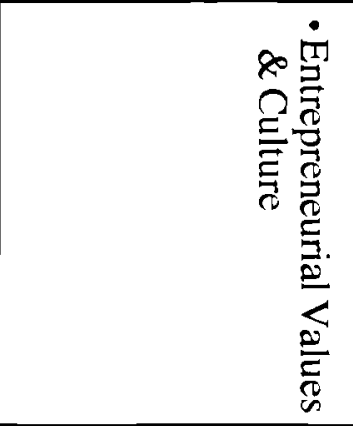 & 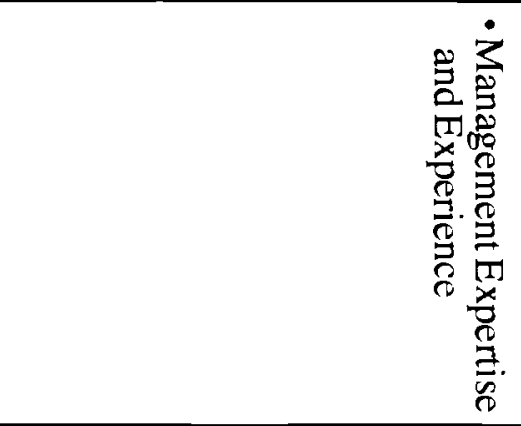 & 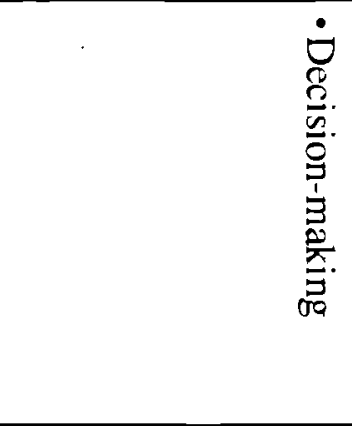 & 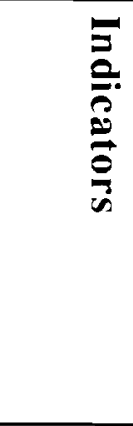 \\
\hline 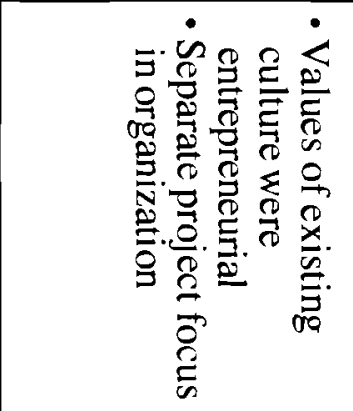 & 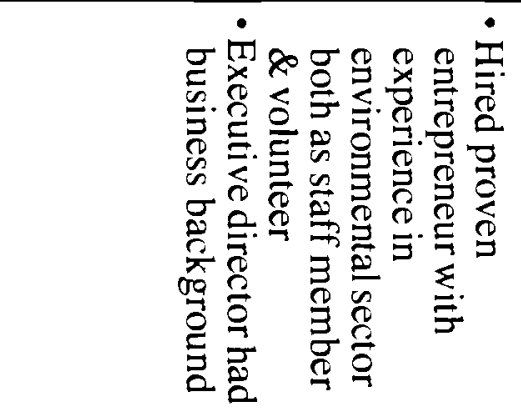 & 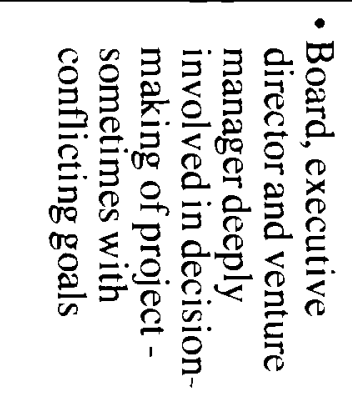 & $\begin{array}{rl}\pi & \pi \\
0 & 0 \\
0 & 0 \\
0 & 0 \\
0 & 0 \\
0 & 0 \\
0 & 0 \\
0\end{array}$ \\
\hline 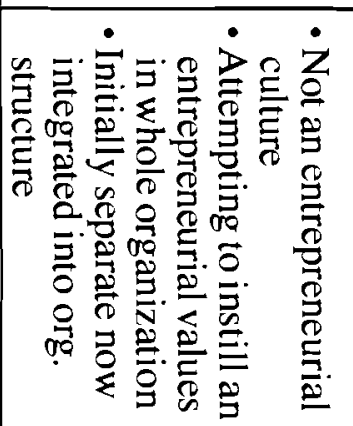 & 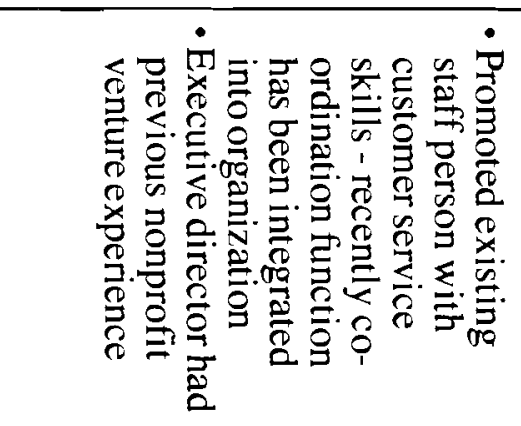 & 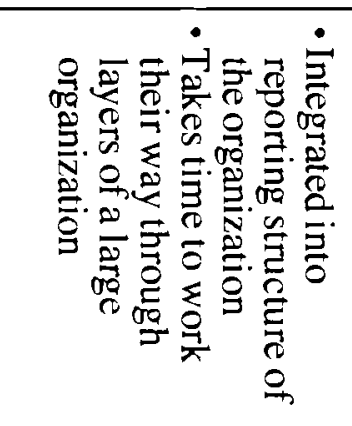 & 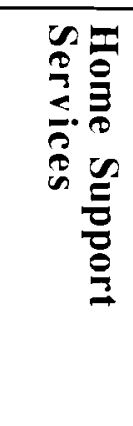 \\
\hline 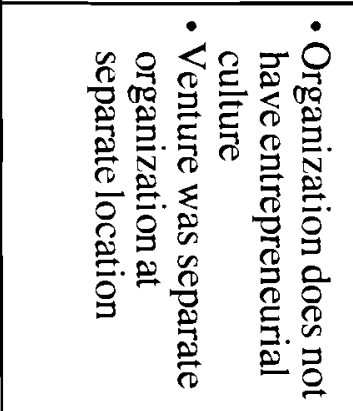 & 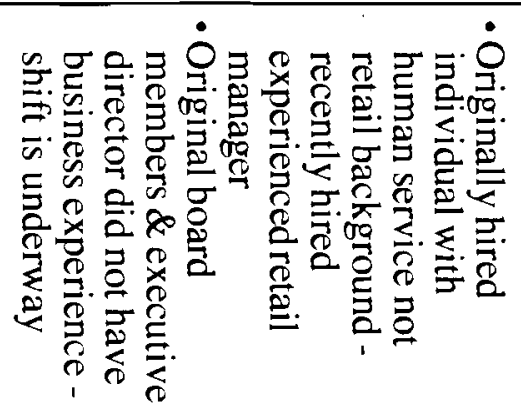 & 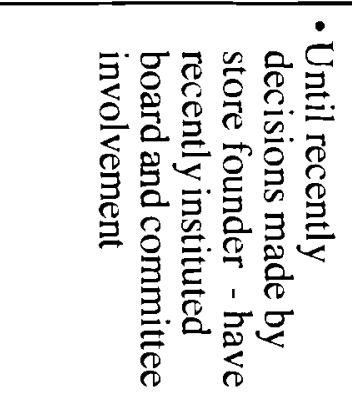 & 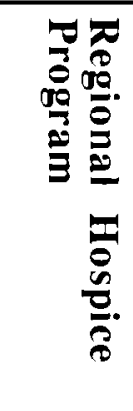 \\
\hline 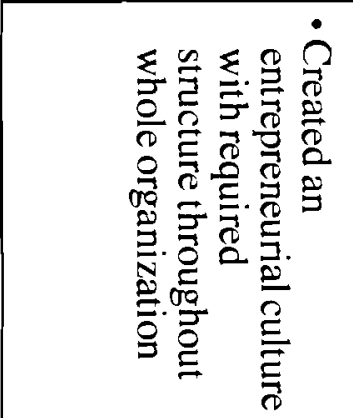 & 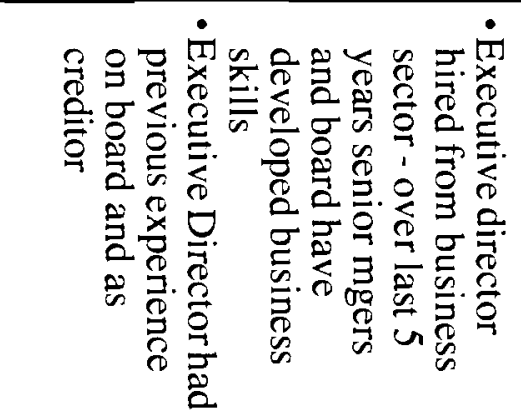 & 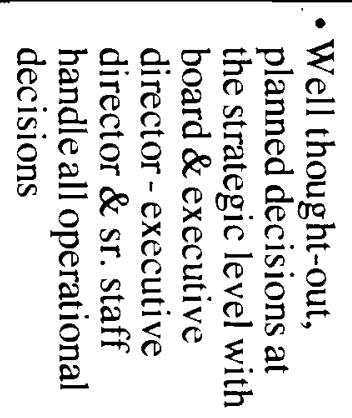 & 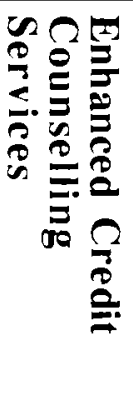 \\
\hline
\end{tabular}


Quadrant \#3 - Degree of Support for Venture/ External Environment

\begin{tabular}{|c|c|c|c|c|}
\hline Indicators & Reduce, Reuse, Recycle & Home Support Services & $\begin{array}{l}\text { Regional Hospice } \\
\text { Program }\end{array}$ & $\begin{array}{l}\text { Enhanced Credit } \\
\text { Counselling Services }\end{array}$ \\
\hline $\begin{array}{l}\text { - Current Funders, } \\
\text { Donors \& Clients }\end{array}$ & $\begin{array}{l}\text { - Venture clients do not } \\
\text { connect venture to the } \\
\text { organization } \\
\text { - Some stakeholders } \\
\text { opposed for } \\
\text { ideological reasons - } \\
\text { may affect donations }\end{array}$ & $\begin{array}{l}\text { - Venture clients do not } \\
\text { know that they are } \\
\text { supporting HSS - } \\
\text { they are interested in } \\
\text { service and cost } \\
\text { - Donations could } \\
\text { ultimately be affected } \\
\text { - Funders support new } \\
\text { ways of creating } \\
\text { revenue }\end{array}$ & $\begin{array}{l}\text { - Venture clients know } \\
\text { funds go to charity } \\
\text { but do not know } \\
\text { much about hospice } \\
\text { - Funders encourage } \\
\text { fundraising ventures } \\
\text { - Donors of clothes } \\
\text { support charitable } \\
\text { purposes }\end{array}$ & $\begin{array}{l}\text { - Clients see an } \\
\text { integrated service/ } \\
\text { organization } \\
\text { - Donors approve and } \\
\text { support } \\
\text { entrepreneurial culture }\end{array}$ \\
\hline - Public Perception & $\begin{array}{l}\text { - Organization } \\
\text { unknown by general } \\
\text { public - publicity } \\
\text { coverage of venture } \\
\text { may assist in raising } \\
\text { profile of organization }\end{array}$ & $\begin{array}{l}\text { - Some confusion with } \\
\text { a nonprofit offering a } \\
\text { competitive, market } \\
\text { service }\end{array}$ & $\begin{array}{l}\text { - Confused image - } \\
\text { secondhand clothes } \\
\text { store with } \\
\text { bereavement books in } \\
\text { window }\end{array}$ & $\begin{array}{l}\text { - Organization and } \\
\text { venture are one \& the } \\
\text { same }\end{array}$ \\
\hline
\end{tabular}

Quadrant \#4 - Degree of Support for Venture/ Internal Environment

\begin{tabular}{|l|l|l|l|l|}
\hline Indicators & Reduce, Reuse, Recycle & Home Support Services & $\begin{array}{l}\text { Regional Hospice } \\
\text { Program }\end{array}$ & $\begin{array}{l}\text { Enhanced Credit } \\
\text { Counselling Services }\end{array}$ \\
\hline - Board Support & $\begin{array}{c}\text { Board still has doubts } \\
\text { - some uncomfortable } \\
\text { with goals of venture }\end{array}$ & $\begin{array}{l}\text { No problem indicated } \\
- \text { new board evolving } \\
\text { with entrepreneurial } \\
\text { thinkers }\end{array}$ & $\begin{array}{l}\text { Board went along } \\
\text { with founder - now } \\
\text { board is interested } \\
\text { and is looking at } \\
\text { venture carefully }\end{array}$ & $\begin{array}{l}\text { Initially some } \\
\text { resistance - executive } \\
\text { director brought board } \\
\text { along through } \\
\text { education }\end{array}$ \\
\hline -Champion" & $\begin{array}{l}\text { Manager of the } \\
\text { venture with support } \\
\text { from executive } \\
\text { director }\end{array}$ & •Executive Director & $\begin{array}{l}\text { original founder who } \\
\text { has since left the } \\
\text { organization - now } \\
\text { left with no champion }\end{array}$ & $\bullet$ Executive Director \\
\hline
\end{tabular}




\section{Quadrant \#4 (continued) - Degree of Support for Venturel Internal Environment}

\begin{tabular}{|c|c|c|c|c|}
\hline Indicators & $\begin{array}{l}\text { Reduce, Reuse, } \\
\text { Recycle }\end{array}$ & $\begin{array}{l}\text { Home Support } \\
\text { Services }\end{array}$ & $\begin{array}{l}\text { Regional Hospice } \\
\text { Program }\end{array}$ & $\begin{array}{l}\text { Enhanced Credit } \\
\text { Counselling } \\
\text { Services } \\
\end{array}$ \\
\hline - Infrastructure Support & $\begin{array}{l}\text { - Own staff, physically } \\
\text { together, own phone } \\
\text { line, capital start-up } \\
\text { - Overwhelmed } \\
\text { infrastructure initially }\end{array}$ & $\begin{array}{l}\text { - Now treated as one of } \\
\text { the programs }\end{array}$ & $\begin{array}{l}\text { - No infrastructure } \\
\text { support, no } \\
\text { technology }\end{array}$ & $\begin{array}{l}\text { - Totally integrated, top } \\
\text { of the line technology }\end{array}$ \\
\hline - Structural Integration & $\begin{array}{l}\text { - Separate profit centre } \\
\text { but mirrors way } \\
\text { organization } \\
\text { structured } \\
\text { - Manager reports to } \\
\text { executive director }\end{array}$ & $\begin{array}{l}\text { - Initially a separate } \\
\text { undertaking reporting } \\
\text { to executive director- } \\
\text { now integrated } \\
\text { structurally \& reports } \\
\text { accordingly }\end{array}$ & $\begin{array}{l}\text { - Initially one \& the } \\
\text { same - store became } \\
\text { hospice - reported } \\
\text { directly to Board } \\
\text { - Now reports to e.d. } \\
\text { with board committee } \\
\text { supervision }\end{array}$ & - Totally integrated \\
\hline $\begin{array}{l}\text { - Fit to Value \& } \\
\text { Mission }\end{array}$ & $\begin{array}{l}\text { - Questionable - } \\
\text { recycling cars is an } \\
\text { ideological clash with } \\
\text { the harm cars do to } \\
\text { the environment }\end{array}$ & $\begin{array}{l}\text { - Same service - new } \\
\text { market - from meeting } \\
\text { needs to ability to } \\
\text { choose }\end{array}$ & $\begin{array}{l}\text { - Indirect fit with } \\
\text { charity values } \\
\text { currently - move to } \\
\text { consignment may } \\
\text { cause problems }\end{array}$ & $\begin{array}{l}\text { - Integrated venture } \\
\text { dedicated to } \\
\text { improving service }\end{array}$ \\
\hline - Organizational Culture & $\begin{array}{l}\text { - Matches the culture } \\
\text { but some tension due } \\
\text { to single purpose of } \\
\text { venture - venture } \\
\text { ongoing versus one } \\
\text { off }\end{array}$ & $\begin{array}{l}\text { - Cultures are different - } \\
\text { staff see social service } \\
\text { purpose vs. venture } \\
\text { cleaning service } \\
\text { - E.d. sees venture as } \\
\text { vehicle to model } \\
\text { organizational } \\
\text { transformation }\end{array}$ & $\begin{array}{l}\text { - Initially no conflict - } \\
\text { store was hospice - } \\
\text { issue of consignment } \\
\text { may be a clash of } \\
\text { values - "that isn't } \\
\text { how we do it here }\end{array}$ & $\begin{array}{l}\text { - Major organizational } \\
\text { shift from social } \\
\text { service culture to } \\
\text { ent repreneurial culture }\end{array}$ \\
\hline $\begin{array}{l}\text { - Style of Management } \\
\text { provided to venture } \\
\text { by organization }\end{array}$ & $\begin{array}{l}\text { - Directive \& } \\
\text { achievement oriented }\end{array}$ & $\begin{array}{l}\text { - Supportive \& } \\
\text { achievement oriented }\end{array}$ & $\begin{array}{l}\text { - Originally directive } \\
\text { now supportive and } \\
\text { achievement oriented }\end{array}$ & $\begin{array}{l}\text { - Participative \& } \\
\text { achievement oriented }\end{array}$ \\
\hline
\end{tabular}




\section{FINDINGS FROM THE APPLICATION OF THE MATRIX:}

From the analysis of the four cases, eleven indicators were found to be key to the success of the entrepreneurial ventures, while six were found not to be key to venture success. Discussion of the 6 Non Key Indicators is handled first followed, by discussion of the 11 Key Indicators.

\section{Six Non Key Indicators}

1. Business planning was only used in one case, and then only as a result of pressure from business executives who were on the board. The other organizations did not even consider creating a business plan, although in one case there was a marketing plan. All of the organizations had done strategic planning. It may be that although business planning appears crucial to venture success in the for-profit sector, it does not appear to be as useful in the four cases studies. This is contrary to much of the literature which says that business planning is an absolute must for nonprofit organizations to succeed in entrepreneurial ventures.

2. Knowledge of and attitude toward the competition is critical to success in the for-profit sector. And yet, in all four cases, while the was a general awareness of the competition or at least of those organizations providing similar services and products to the same target markets, the attitude was one of "coopetition". (Whiteley and Hessan 1996. p.39) That is, simultaneously competing and co-operating with another organization.

3. Knowledge of the customer is also supposed to be key to success in entrepreneurial ventures. However, in all four cases, no strong knowledge of the customer or the customer's "wants" existed when the venture began. In one case, the organization had no idea who the customers would be and in another, by moving the same service offering into a different market, they had to learn to think in terms of what customers would pay for rather than what they needed. In the third case, they have an after-the-fact knowledge of their customers and are attempting to attract a different type. In the fourth case, they have only recently established strong tracking mechanisms that allow them to learn about their customers.

4. The attitude of current funders, donors and clients toward the venture should, in theory be important to the success of the venture. And yet, in these four cases, attitudes of clients range from making no connection between the venture and the organization, to seeing the organization and the venture as one. In all cases, funders supported the venture.

Government, the major funder, is anxious to see the organizations develop other revenue sources. Donors attitudes varied among the cases. In RRR, there was a concern by some stakeholders that knowledge of the venture could cause donations to drop because of ideological differences. However, there was no evidence that this was happening. In HSS there was some confusion about a nonprofit offering a competitive market service which they also offered as a social service. There is a concern that this confusion could ultimately affect donations. In the case of RHP, the donors of the clothing know they are supporting charity but really don't know about hospice services. There is a danger that, as the store moves more toward consignment sales, donations may drop off. In ECCS, the donors, who are also the creditors, are an integral part of the service and are totally committed to the organization as an entrepreneurial venture. It would appear that, the attitudes of the funders are more crucial as key indicators of success than those of clients or donors.

5. One would think that the public perception of the venture and its relationship to the organization would also be critical to its success. However, in the RRR case, the public 
who knew about the venture was completely unaware of the "mother" organization. In HSS, the venture was initially thought to be yet another social service offering of the organization. In the RHP case, the perception was totally confused and most people didn't know what the store was all about. In about 800 square feet of space, one could find used clothes, books on dying and bereavement counselling. Until recently, the hospice itself was hidden away in a small hospital office. Finally, in ECCS, once the culture change was completed, the venture became the organization.

6. The degree of infrastructure support (e.g. space, technology, equipment) would also seem critical to success. Yet the infrastructure support experienced by the four ventures ranged from none at all to state of the art accommodations and technology.

\section{Eleven Key Indicators:}

The indicators that were found to be key to the success of the venture in the four cases are:

1. Market awareness: All four cases either had studied their market initially or were now in the process of doing so.

2. Trends: Either by luck or through knowledge gained in carrying out their mission, all four cases had established their ventures in areas where there were strong trends for customer growth.

3. Decision-making: Each of the decision-making processes was unique to the needs of the "mother" organization and the venture. Yet in each case the decision-making process was clearly understood by those involved. The process demonstrated a balance between the needs of the venture and the mission of the organization in order to meet multiple bottom lines.

4. Management Expertise and Experience: In all four cases management had experience both as an entrepreneur and in the nonprofit sector. Managers were adept at managing ambidextrously. "Philanthropreneurship...needs much more in a leader than a perfunctory business-as-usual involvement in the enterprise. Instead, it seems to require in one person an amazing blend of a passionate visionary with the acute business sense of a savvy supply sergeant who can somehow, some way, find the right stuff when it is needed to get the job done." (Philanthropreneurship Newsletter On-Line, 1998)

5. The existence of entrepreneurial culture in the organization is a borderline key indicator. The researchers have chosen to include it because it is clear that, while a venture can succeed without it, it will be at great cost to all involved.

6. Board support, not just passive acquiescence but a strong supportive presence, is another key indicator. This includes the boards' careful examination of the risks involved in starting the venture and on-going role in monitoring the progress of the venture. The boards in our four cases varied in the way they became committed to the venture, but all ultimately provide the necessary support. In RRR, there is still some concern regarding the fit of the venture to environmental values. However, despite this concern, the board has fully backed the venture. In the case of HSS the board is totally supportive. In the case of 
RHP, the board was only nominally involved at first, but is now playing an active role. In the case of ECCS, the board has developed entrepreneurial thinking along with the rest of the organization.

7. In all our cases, there was a strong "champion" for the venture. In fact, RHP is now actively looking for another champion, as the founder of the venture has left the organization. It is hoped that the new store manager will become the champion or that one will emerge from amongst the new board members.

8. The degree to which the venture is structurally integrated into the organization is unique, but critical in each case. The key to success appears to be that the structural integration between the venture and the organization is well thought out and facilitates the goals of both the venture and the mission of the organization. The varied structural integrations among each of our cases are consistent with this premise. In RRR the reporting structure is integrated but the financial structure is separate. As the whole organization is composed of self sufficient profit centres, having each project manager report to the Executive director is one way of ensuring integration. In HSS, the venture was initially a stand alone enterprise reporting directly to the executive director. However, as there is a strong desire to build an entrepreneurial culture throughout the organization, the executive director has decided that the venture should be treated as any other program and thus become a role model. In RHP, the store and the hospice were at first one and the same. Now, with RHP achieving structural independence from the hospital, the store is working out its integration issues with the "mother organization". The goal is to have the store concentrate on what it does best, while the hospice concentrates on what it does best. In ECCS, the thinking necessary to conceive a venture quickly took over the entire organization.

9. The fit of the venture to the mission and the values of the organization is described in the literature as key to venture success. For two of our cases, HSS and ECCS, this is true. In the RRR case, the organization itself has conflicting values between "deep environmentalists" and "mainstream environmentalists". Therefore, although the venture fits the values of one part of the organization, it can be seen as conflicting with the other. In RHP, running a used clothing store has nothing what so ever to do with the mission of the hospice. However, there is a long historical tradition of these "charity stores" supporting hospice programs and RHP was able to tap into this historical experience.

10. The match of organizational culture is recognized in the literature as critical and yet is often very difficult to achieve. Rather than an exact match perhaps we a talking about degree of fit to the unique circumstances of the venture and its organization. In RRR, on the surface there is an exact match between the venture and the organization. However, there is an underlying tension caused by different meanings around education, time management and response to customers. In HSS, the cultures are very different although the service provided is the same. This is illustrated by the different cleaning staff behaviours. The staff that provide home cleaning as a social service socialize comfortably with one another, while the home cleaning staff see the relationship as part of a business arrangement. This cultural difference worked well when the venture was separate from the organization. Now that it is structurally integrated it will be interesting to see which culture wins out. Research shows that two disparate cultures will not co-exist for long. One will over take the other. This is what happened in ECCS where, through a conscious effort on the part of the ED, there is just one big entrepreneurial culture. In RHP, there was initially no conflict as the hospice and store were one. The store really did not have an entrepreneurial culture and thus was not realizing its potential. In this case the recent separation of the venture and the organization will allow both cultures to strengthen and find a way of interfacing. 
11. Style of management provided to the venture by the organization was a key indicator in these four cases. House, in his path-goal theory, sets out four management styles that may be used alone or in combination. These styles are Directive (hands on management), Supportive (encouragement and empathy), Participative (shared decision making), and Achievement-Oriented (goal setting). The management style(s) used must fit the unique situation and personal needs of the key players.

In RRR a directive and achievement-oriented style was used. The venture manager, while responsive to the achievement-style of goal setting, railed against the directive style seeing it as a challenge to his knowledge, experience and commitment. The manager in the venture in HSS thrived under the supportive, yet achievement-oriented management style provided by the executive director of the large formalized organization.

In RHP, the initial venture manager received no formal management from the organization. As the venture really was the organization, and the store manager was a close friend of the founder of RHP, she probably received informal management in the form of personal support. The store now has a new manager and the board and executive director are taking an active management role. As both are new to their roles; the management style used both formally and informally is a combination of "directive", "supportive", participative, and achievement-oriented. In ECCS, The executive director and the Board provide a participative/achievement oriented style of management which is very successful.

\section{CONCLUSION}

The key indicators described above apply only to the four cases discussed in this paper. However, some may be generalizable to other nonprofit ventures or at least their consideration may offer insights to other organizations embarking on ventures. These insights may help inform the thinking necessary to prepare for such a venture. For example, an achievement-oriented management style appears to be necessary if the venture is to be productive in the business sense. This management style involves developing concrete revenue targets to be achieved. This differs from traditional nonprofit management styles where financial goal setting is focused on budgetary control.

It was clear from our research that the dynamics and issues that surround the original decision to commit to the venture impact heavily on its success. Interestingly, all our organizations started their ventures in response to a need for money. Three out of the four organizations embarked on their ventures when faced with immediate financial crises. This is contrary to the theoretical wisdom which says " An organization should not begin looking at a business venture when it gets into trouble. People don't do their best thinking in a crisis." (Brinkerhoff, 1990)

Traditionally money has been a "dirty" word in nonprofit organizations. They saw themselves as above the fray of organizations dedicated to making a profit. Richard Steckel (1995) states "that nonprofit entrepreneurs like money rather than fear it." It is interesting to note that in all four cases, the organizations reframe the venture, to a greater and lesser degree, to make a more comfortable fit between the "money-loving" venture and the "money-fearing" organization. In RRR, the venture was reframed as a way of educating the general public, despite the fact that many of the venture customers were unaware of RRR and its mission. In HSS, the venture was cast in the role of "Robin Hood", selling a desired service to those who could pay in order to provide a needed service to those who could not pay. In RHP, the venture was originally framed as the "public face" of the organization. Now that RHP has its own public face, the role of the venture is being redefined. In ECCS, the venture was reframed as the saviour for the service, another "Robin Hood" strategy of selling to the rich in order to provide service to the poor. 
A surprise for the researchers was the role that careful planning did not play when the four organizations embarked on their ventures. With one exception, where outside pressure (non nonprofit influences) forced a business plan, the ventures seemed to spring from the hearts of the organization. As one interviewee said "The organization's experience with business came from the Andy Hardy School of Administration - I got a barn, I can sing, you can dance, so let's do Broadway."

There is much research left to be done, this paper only scratches the surface of illustrating how Canadian nonprofits embark on entrepreneurial ventures. More case studies need to be gathered to provide a richer picture of the usefulness of the key indicators. The actual questions used to gather information in each of the four quadrants of the matrix need further refinement, but show promise in determining the capacity of nonprofit, charitable organizations to initiate and grow successful ventures. In the future, research on the indicators employing correlational methodology may provide valuable tools for nonprofits to use when determining the probability of their success with entrepreneurial ventures. 


\section{APPENDIX I}

The following set of semi-structured interview questions used to gather data in the two cases researched in Phase II.

1. Tell us about the history/background/mission of your organization. What were the circumstances surrounding your organization's decision to embark on an entrepreneurial venture? Who in the organization was involved in making the decision? Describe your organization's culture. What are the attitudes towards new ways of doing things? Describe how the culture has changed since embarking on the entrepreneurial venture.

2. Describe the venture and how it evolved from an idea to where it is today. What kinds of thinking/planning went into the development of the venture? Was a business plan developed? What did it include? What did you know about your market/trends when you entered the venture? Today? Who is the competition for the venture? What did you know about them when you entered the venture and what do you know about them today?

3. Describe the physical location and set up of the venture.

4. Was a communications plan, including public relations, advertising and publicity, created to launch the venture? What types of communication tools are used now?

5. Is the venture making a profit, breaking even or depending on the "mother" organization for financial support? Describe the evolution of the ventures' financial state since its inception.

6. How does the venture relate to the "mother" organization in terms of structure, staffing, values, skill sets, and fit with the mission. Is the pace of the work in the venture different from the pace of the work in the organization? How is information communicated between the venture and the organization? How are differing priorities resolved between the venture and the "mother" organization?

7. Does the leadership of the organization differ from the leadership of the organization? Where are the skills necessary to run the venture located? Who is the "champion" of the venture and where is that person(s) located in terms of the structure of the organization and the structure of the venture?

8. Tell us about the challenges, struggles and high points experienced as the venture has evolved. What were the sticking points encountered? Describe the effect of the venture on the culture of the "mother" organization. How were the differences in language, meanings and priorities between business and service resolved? What value schisms occurred? Where, among all stakeholders, was the support and opposition to the venture? How did these stakeholders react to the venture at the beginning? How are they reacting today? How did this change as the venture evolved? Where and how are venture decisions made? Who makes them? How do the needs of the "mother" organization impact on the decision of the venture? 
9. Where did the "mother" organization get the start up capital for the venture? How much was needed? How are the monies earned by the venture handled now? Do they flow directly into the common organizational resources? Does the venture management have a "say" in how the venture monies are to be use in the "mother " organization?

10. What were the technological changes needed to start up the venture? Have there been any other technological impacts due to the venture?

11. Are the "mother" organization's volunteers involved with the venture? In what ways?

12. Do you consider the venture a success? Has it achieved the goals that were set for it? 


\section{Bibliography}

Argyris, C. (1990). Overcoming Organizational Defenses: Facilitating OrganizationalLearning. Boston: Allyn and Bacon.

Barlett, C.A. and S. Ghoshal (1994). "Changing the Role of Top Management: Beyond Strategy to Purpose." Harvard Business Review (November-December): pp.79-88.

Bowen, W. (1994). "When a Business Leader Joins a Nonprofit Board." Harvard Business Review (September-October).

Brinckerhoff, Peter C. (1990). "Mixing Business and Mission: How Should a Board Decide?" Nonprofit World Vol. 8, No. 3 pp 9-10.

(1993). "Watershed or Waterloo? Two Key Steps in Business Development" in The Society for Nonprofit Organizations' Leadership series Enterprise (for-profit) Endeavors . WI. pp.98-99

(1994a). "How to Tum Your Entrepreneurial Skills Toward Your Mission." Nonprofit World Vol. 12, No. 4 pp. 17-19

(1994b). "How to Keep Your Funders Happy as you Develop Your Business." Nonprofit World Vol. 12, No. 6 pp. 18-20.

(1994c). "Is Profit a Dirty Word?" Nonprofit World Vol. 12, No. 1

(1995d). "A New Way to Think About Your Markets." Nonprofit World Vol. 13, No. 1.

Budd, J. (1996). "How Are Nonprofits Using Business Ventures?: Advice From The Front." Nonprofit World Vol. 14, No. 3 pp 40-2.

Collins, Jim. (1996) "Aligning Action and Values." in LeadertoLeader Vol.1 No.1.

Dees, J. Gregory (1998). "Enterprising Nonprofits." Harvard Business Review (JanuaryFebruary) pp. 55-67.

Embly, L. (1993). Doing Well by Doing Good: The Marketing Links Between Business and Nonprofit Causes. Englewood Cliffs, NJ: Prentice Hall.

Emerson, J. and F. Twersky (eds) (1996). New Social Entrepreneurs: The Success, Challenge and Lessons of Non-profit Enterprise Creation. San Francisco: The Roberts Foundation.

Emerson, J. (1997). "Top 10 List: Famous Last Words of Failed Nonprofit Entrepreneurs." Nonprofit World Vol. 15, No. 4 (July-August).

Foster, Mary and Agnes Meinhard (1996). "Towards Transforming Voluntary Social Service Organizations in Ontario." Toronto: Ryerson Polytechnic University. 
(1993) "Ventures Need Champions." in The Society for Nonprofit Organizations' Leadership series Enterprise (for-profit) Endeavors. WI. pp. 54-55

Social Planning Council of Metropolitan Toronto (1995). "Community Agency Survey: Metropolitan Toronto." Metro Community Services, City of Toronto.

Steckel, R. 'Developing an Entrepreneurial Vision." Nonprofit World.

Steckel, R. (1989). Filthy Rich and Other Nonprofit Fantasies. Berkley: 10 Speed Press.

Tichy, N. M. and Sherman S. 1993. Control Your Destiny Or Someone Else Will. New York: Doubleday.

Westley, F. and H. Vredenburg (1991). "Strategic Bridging: The Collaboration between Environmentalists and Business in the Marketing of Green Products." Journal of Applied Behavioural Science 27 (1): 65-90

Whiteley, Richard and Diane Hessan (1996). Customer Centred Growth . Boston: Addison Wesley Publishing Co.

Wilson, Leslie L. "Anatomy of a New Nonprofit Venture." Nonprofit World Vo. 7, No. 2. WI.

Worley, Christopher G., David E. Hitchin and Walter L. Ross 1996. Integrated Strategic Change. Toronto: Addison Wesley Publishing.

Zimmerman, Brenda and R. Dart (1998). Charities doing Commercial Ventures: Societal and Organizational Implications. Trillium Foundation and Canadian Social Policy Networks Inc. 